\title{
A NATIONAL TRANSPORTATION POLICY
}

\author{
Robert R. Young*
}

I

The National Transportation Policy is expressed in the Federal statutes, principally the Interstate Commerce Act and the several supplementary acts among which should be mentioned the Railway Labor Act, the Bankruptcy Act, the Panama Canal Act, and the Clayton Antitrust Act. The Civil Aeronautics Act applies to transportation by air. These Federal statutes embrace the policy of the Congress affecting transportation. The policy so defined must conform to the antitrust laws except in those instances where relief is given as in section 5 (II) of the Interstate Commerce Act. ${ }^{1}$

The framework of the existing policy is the result of an evolutionary process. Congress has frequently amended the statutes. Many of these amendments have wrought far-reaching changes in the principles of regulation and the powers of the Commission. The Transportation Act of 1920 and the Transportation Act of 1940 both changed the regulatory process affecting the railroads. Appropriations by Congress for aid in highway construction, for the development of inland waterways, or for construction of airports may seriously affect the welfare of the railroads or other carriers. Those acts of Congress which provide such subsidies or tax differentials for any mode of transportation, after its development period is past, may be viewed as modifications of the National Transportation Policy or as exceptional incidents inconsistent with the policy. Congress is the master of the policy.

That part of the policy which affects the making of interterritorial freight rates and prohibits discrimination is as old as the Interstate Commerce Act. It is the duty of every railroad to establish reasonable through routes with other railroads and reasonable rates applicable thereto and to establish classifications and regulations. Unjust discrimination, undue or unreasonable preference or advantage, or undue or unreasonable prejudice or disadvantage, are prohibited. Thus, the law puts these duties on the carriers and imposes penalties for violations. Any person may complain to the Commission; that body has the duty of investigating the complaint and the power to prescribe relief.

Many complaints affecting interterritorial freight rates have been filed with the Commission, especially during the last twenty-five years, and the Commission has ordered many adjustments. Complaints related in most cases to the rates applicable to the movement of manufactured products from the South to the eastern or official

\footnotetext{
* Chairman of the Board, the Chesapeake \& Ohio Railway Company. The author acknowledges the assistance and helpful suggestions given him in the preparation of this article by Messrs. Robert W. Purcell, R. S. Marshall, W. H. Wenneman, and James Condren, Jr., of the Chesapeake \& Ohio staff.

${ }_{24}$ StAT. 380 (I887), as amended, 49 U. S. C. $\$ 5$ (II) (I940).
} 
territory. Upon its own motion, the Interstate Commerce Commission finally instituted a general investigation of existing class rate and classifications in I939. In May, I945, after long hearings, the Commission entered an order requiring the establishment of a uniform level of class rates and classifications throughout the entire United States east of the Rocky Mountains. Since it would take several more years to complete the required revisions, the Commission sought to give some measure of temporary relief by entering an interim order which reduced class rates by ten per cent in the South and West and interterritorially, and increased class rates within the East by the same percentage. ${ }^{2}$ This order was enjoined on petition of several northern states and a large number of western railroads, but was upheld by the United States Supreme Court in May, r947, after two years of litigation. ${ }^{3}$ Slow motion appears to be the current strategy of those whose interests are contrary to the adjustment of rates.

Our transportation statutes provide penalties for violations of the law but intend that such violations shall not occur. The primary duty of dealing fairly with the public is imposed on the carriers. Good business policy demands that the patron shall be well and faithfully served. Progressive business institutions recognize that the customer is always right. The fact that so many complaints were filed and so many rate adjustments were ordered by the Commission, in the past two or three decades, strongly indicates that the railroads were not alive to the needs of commerce. They seem to have failed to adjust their prices to the developing requirements of their customers.

Common sense and business judgment support the presumption that complaints about rate discrimination arise from conditions that can be corrected with mutual benefit to the railroads and the public. There must have been underlying reasons for the chronic condition complained of by business interests in the South and the West. In view of the known relationships and close control exercised by the New York bankers over the railroads of those regions and over the industries in the East, the initiated can guess one underlying reason why rates were kept high in the South and West. The hidden cartel could protect the industries which the bankers already controlled in the East and attract new ones to that territory rather than to the South and the West. The ensuing pattern did not need to take the form of raising rates in the South and the West but could content itself with fostering reductions in the eastern rate structure as against lack of action elsewhere. It was to the interest of the New York bankers to promote and maintain any rate differential which resulted in favor of the East. In this aura of monopolistic intent, the presumption naturally arises that the controlling group was not concerned with developing rates appropriately adapted to the needs of commerce and industry except in the East. It is not surprising that recently the remedies provided by the antitrust laws have had to be invoked in rate matters rather than those available in the Interstate Commerce Act.

${ }^{2}$ Class Rate Investigation, 1939,262 I.C.C. 447 (1945).

${ }^{3}$ See the Foreword to this symposium. [Ed.] 
The general administration of this National Transportation Policy affecting carriers other than air carriers is delegated to the Interstate Commerce Commission. Certain duties and responsibilities for initial action are imposed on the railroads, and steps they take are generally subject to the review of the Commission.

In the Transportation Act of I940, the Congress summarized National Transportation Policy as follows:

To provide for fair and impartial regulation of all modes of transportation subject to the provisions of this act, so administered as to recognize and preserve the inherent advantages of each; to promote safe, adequate, economical, and efficient service and foster sound economic conditions in transportation and among the several carriers; to encourage the establishment and maintenance of reasonable charges for transportation services, without unjust discriminations, undue preferences or advantages, or unfair or destructive competitive practices; .... all to the end of developing, coordinating, and preserving a national transportation system by water, highway, and rail, as well as other means, adequate to meet the needs of the commerce of the United States, of the Postal Service, and of the national defense. ${ }^{4}$

Notably, the Congress did not cease with a statement of the end to be attained. It further provided that all the provisions of the Interstate Commerce Act shall be administered and enforced with a view to carrying out this declaration of policy.

The Interstate Commerce Commission, sad to report, reaches a sixtieth birthday this year with its principal ward highly unprepared to meet the new transportation day of 1947. It is likewise a tragic commentary on the effective exercise of the Commission's powers and duties through sixty long years that, at this late date, a symposium can still be organized by Law and Contemporary Problems on interterritorial freight rate discrimination. This paper does not propose to present or discuss all our thoughts on the National Transportation Policy but to single out for analysis certain factors which nurture rate discrimination and to reveal why and how they do it.

All railroad problems, whether they be those today concerning rates and ratemaking, banker-controlled railroad policies, inadequate financial return, the emergence and importance of aviation, or the inequities of subsidy and taxation, call for thoughtful but decisive action. At such time, little can be gained by bemoaning the past and it is axiomatically fatal to follow the time-honored railroad practice of living in it. Progressive thought in the railroad industry does not belabor the Interstate Commerce Commission in these critical days to deter it but to awaken it to a proper exercise of its designated powers and activation of its assigned policy.

\section{II}

Hovering in the background of the charges and denials of interterritorial freightrate discrimination is the small clique of eastern bankers that has dominated the railroad industry since its earliest days without a dollar of permanent ownership. Defenders of the status quo, it is natural that they would exert their financial power

‘ 54 STAT. 899, 49 U. S. C., note preceding \$I (1940). 
to oppose expansion of industry in the South and West that would be detrimental to the long-established, banker-and-trustee-controlled industries of the North. Their plan for monopoly was the artificial protection of vested interests in one section of the country at the expense of the people as a whole. Control of the railroads brought large collateral advantages to the bankers in such forms as lucrative emoluments from financing services, stock transferships, paying agencies and trusteeships, power over vast amounts of bank deposits, and control over purchasing, salaries, jobs, fees for insurance, legal services, advertising, and auditing.

Even the depression of the Thirties, which forced into bankruptcy most of the ill-nurtured railroads of the South and West, could not dislodge the power of this ruling clique. It met the crisis head-on. This little group of bankers, with their nominees, through lightning change of costume, emerged as protective committees for the security holders to reorganize the railroads and relaunch them in sound condition. One of their new garbs was the voting trust. This odious device usurped the voting rights of the stockholders and vested complete control of the railroad, its directors, and its officers in the hands of trustees. When the Congress wrote legislation planning to abolish abusive power and privilege inherent in the offices of executives and directors, ${ }^{5}$ it overlooked the fact that the voting trustee was their absolute master in the case of the bankrupt carrier.

The Interstate Commerce Commission, which has the duty to supply the daily ration of the carriers and maintain their health in normal times, should not likewise be charged with making the plan of rehabilitation after it has permitted a breakdown. The Commission is a bi-partisan body of eleven men appointed by the President and charged with the preservation of a sound transportation system. Although the term of each is seven years, tenure can be extended by reappointment for life. This naturally makes the Commissioners eager for continuance in office and keenly responsive to the influence of pressure groups.

The labor and shipping groups are well organized and outspoken in stating their demands to the Commission. The railroad security holders are not. A policy of liberal wages and negligible rates on the part of the Government can quiet labor and shippers but is of scant benefit to security holders. The two-pronged attack of labor and shippers brought on many railroad reorganizations which wiped out interest-paying debt and dividend-paying stock.

With the Interstate Commerce Commission's approval, the New York group swept away the property rights of the investor in exchange for voting trusts. The forfeiture which took place did not merely shift title from an equity holder to a creditor as in the case of a farm or home foreclosure. The senior holder was also scaled down in order that voting stocks might be received in exchange for non-voting bonds.

No doubt Wall Street was surprised at the eagnerness with which Washington joined the scheme. The bankers were to continue in even tighter control than pre-

${ }^{5}$ Securities Exchange Act, 48 STAt. 88I (1934), I5 U. S. C. \$78a et seq. (r940). 
viously. Old stockholders were to disappear. The new ones created through the drastic dilution of bonded debt were to have no voice in the management of the company. This complete disenfranchisement of the owner was to occur even if the bondholders reduced or sold their holdings before the reorganization was completed, as has been done in many cases. Thus in the Thirties, 37 of our $1_{35}$ Class I railroads, representing 25 per cent of total railroad mileage, went into bankruptcy. Many of these companies are still there after ten, twelve, and fifteen years in spite of the fact that they are now in a stronger cash and physical condition than many solvent carriers.

When a bill ${ }^{6}$ to provide for a voluntary modification of the financial structure of railroads was introduced in Congress early in 1946 the following background of the problem was presented:

The bill enables railroad companies to adjust their financial affairs quickly, economically, and on a business basis....

The existing law, section 77 , was enacted in $x 933 \ldots$ in the belief that it would help railroads to correct their financial affairs. It was found to do the opposite. It has placed in the hands of Government officials extraordinary power... :

(r) to demolish every part of the financial and corporate structures of those railroads;

(2) to plan in every respect the financial and corporate future of those railroads;

(3) to pick men to control those railroads; and

(4) to decree the forfeiture of $\$ 21 / 2$ billion of investments.

The present bill puts an end to every one of those powers and restores the operation of railroads to their managements. ... ${ }^{7}$

The bill passed both houses by an overwhelming vote in the closing days of the last session only to be vetoed by the President. ${ }^{8}$ True, the President said he believed the next Congress could formulate a better bill. This was small consolation to the victims who had fought an uphill fight for nine long years and were quite content with the bill as passed by Congress. The pressure of other matters may smother sentiment for a new bill in the present Congress and the President made no promises to urge such a bill. He likewise did not call upon the courts, the Interstate Commerce Commission, and other parties in interest to suspend progress of pending reorganization plans in spite of the following warning from the Senate Committee:

The problem is pressing because if something is not done-and done quickly-two great wrongs which cannot be righted subsequently will have been carried to fruition:

(a) the savings of hundreds of thousands of American families will have been irrevocably wiped out (in fact, $\$ 850,000,000^{\circ}$ of such investments already have been wiped out beyond recall); and

(b) an additional large part of the Nation's railroads will fall under control of a half dozen powerful New York financial institutions. ...

'S. 1253, 79th Cong., 2d Sess. (1946).

"SEN. REP. No. II70 on S. 1253, 79th Cong., zd Sess. I-2 (1946).

${ }^{8}$ U. S. Code, Congressional. Service, 7gth Cong., 2d Sess. I713-1714 (1946). See Insurance Group Committee v. Denver \& R. G. W. R.R., 67 S. Ct. 583, 589 (1947).

${ }^{\circ}$ The amount was $\mathrm{r}, 080$ million dollars at the time of the President's veto. Since then, it has been increased by 188 million dollars. 
Forfeitures are taking place, or are contemplated, that have no basis in equity or moral right. ${ }^{10}$

The monopolization of railroad policy by this banker-Government alliance can be further shown over and over through the pattern of uniform action which it fostered. First there was the campaign of opposition to competitive bidding for railroad securities. When this plan was advocated, it appeared as though there were only two railroads in the country: one controlled by the Alleghany Corporation and the other by the House of Morgan. The Association of American Railroads appeared before the Commission representing all the railroads except the Chesapeake \& Ohio Lines and urged that the bankers be kept in their position of preference. Such intervention of management against security holders was a gross violation of obligation.

Then again, about V-J Day a meeting was held in Washington by the railroads operating sleeping cars. They agreed to petition the District Court at Philadelphia for two years' delay in its decree in the Pullman antitrust case ${ }^{11}$ for no apparent reason other than to enable the Pullman monopoly to enjoy two more years of high traffic earnings with old equipment. The nation's sleeping car plant had long since passed obsolescence and could not be rejuvenated for years. Its nearly seven thousand cars averaged about twenty-two years in age. If the railroads had an effective sales organization and up-to-date methods of promotion to tap the rail travel potential, they would need fourteen thousand new sleeping cars. If the railroads were then to keep pace with all modern improvements as developed, an annual replacement rate of about two thousand sleeping cars a year would be necessary. Yet, subsequent litigation brought rejection of offers for the Pullman business by independent, progressive bidders and a mere transfer of the old type of management to a railroad pool ${ }^{12}$-such is the power and luck of monopoly.

The pattern was also demonstrated by actions of the voting trustees of most of the bankrupt railroads. It took such forms as the hoarding of cash in favored banks and the failure to extinguish debt at a discount by open-market purchase.

Nowhere was there deviation from the monopoly pattern. Air conditioning in day coaches was discouraged by illegal agreements. Such lack of interest in modernization was a natural result of the failure to encourage competition in the manufacture of new equipment. A principal reason why we have not scratched the surface of the railroad travel potential has been the lack of attractive equipment and services. Railroad passenger traffic must comprise ( $r$ ) speed, (2) frequency, (3) price, and (4) comfort and attractiveness, plus merchandising.

Probably the most patent indication of our monopoly pattern was presented by the complaint, filed by the Department of Justice in I944 against the Western Association of Railway Executives (whose top committee meetings were held in Wall

${ }^{10} \mathrm{SEN}$. REP. No. II70, cited supra, note 7, at 6-7.

11 United States v. Pullman Co., 64 F. Supp. 108 (D. C. Pa. 1945), aff'd by equally divided cortrt, 67 S. Ct. 1078 (1947).

12 Ibid. 
Street) and others, ${ }^{13}$ alleging that their railroads had under written agreement, entered into in 1932, agreed (among other things):

(a) to impose upon shippers in the Western District freight rates which are higher than those fixed by defendants and their co-conspirators for comparable service to shippers in the Eastern District; ... .

(g) to deprive shippers of perishable products of competitive transportation rates and services by holding cars of perishables shipped from the Western District upon side or spur tracks in order to delay their delivery at eastern destinations; . . .

(1) to disconnect and place out of operation aircooling equipment on cars coming from connecting railroads which had installed such equipment;

(m) to prohibit the installation and provision of various recreational facilities, including motion pictures and radios, upon trains operated by defendant railroads;

(n) to refrain from solicitation of certain types of low-rate passenger traffic;

(o) to eliminate competition by restricting the individual railroad's right to advertise and solicit business.

Early in I947, the Chesapeake \& Ohio group of railroads withdrew from the Association of American Railroads in protest against some of the Association's practices. Subsequent to their resignation from the Association, our railroads have actively supported the formation of a new organization to represent the public, railroad security holders, railroad labor, railroad management, and financial institutions, as well as individuals interested in the progressive development of the American railroads. Named the Federation for Railway Progress, it will campaign actively for new equipment and improved services, for a balanced wage and rate structure, for progressive management, and for return of free enterprise to railroads.

The purpose of reviewing these monopolistic practices has been to show the reason why change in the present transportation structure is opposed by persons who control the destinies of the railroads today. So long as their emoluments continue and the Wall Street bankers succeed in perpetuating themselves in the industry, there is little likelihood of eliminating the inequities of which the shippers in the South and West complain. There must be an end to such combinations which restrain transportation services required by the law and the public interest.

III

The railroads receive an inadequate return on their investments and because of this are in constant danger, as they have insufficient reserves in the event of a business recession. They must, therefore, oppose rate reductions until legal discrimination is found to exist. Therefore, so long as general revenues from all sources are too low, we may not expect voluntary elimination of rates which are claimed to be unreasonable or discriminatory.

It is the aim of the National Transportation Policy, established in 1940 , to set reasonable charges for transportation. services with a view to developing, coordinating, and preserving our national transportation system. The Commission is directed to give proper consideration to the effect of rates on the movement of traffic; to the

${ }^{23}$ United States v. Association of American Railrcads, 4 F. R. D. 510 (D. C. Nebr. I945). 
public need of adequate and efficient transportation service at the lowest cost consistent with the rendering of such service; and to the need of revenues adequate to permit the carriers under honest, economical, and efficient management to provide such service.

In determining the need of revenues sufficient to enable the carriers to provide adequate and efficient transportation service, one simple test which the Commission can apply is the relation of net railway operating income to the needs of the carriers for fixed charges and net income large enough to maintain credit. The need for Commission action would appear beyond question when the earnings of many important carriers are not enough to cover fixed charges. Another test, which in rg20 was prescribed by the Congress and has since been applied by the Commission, is the adequacy of the rate of return on the value of the property.

In April, 1946, carriers applied to the Commission for rate increases estimated to yield about I 9 per cent in increased revenues. The Commission allowed certain small increases effective July $\mathrm{I}, 1946^{14}$ Finally in December, it raised the July increases to 17.6 per cent and made them effective as of January $I, 1947 .{ }^{15}$ In a report issued in February, I947, the Commission stated that the net railway operating income for the year 1946 was 3.I6 per cent of the approximate value of the railroads for rate-making purposes as set by the Commission as of January I, r945. However, when adjustment was made to eliminate unusual items from the r946 income, consisting chiefly of about ryo million dollars in carry-back tax credits, the report stated that the net railway operating income was lowered to only 2.29 per cent of the valuation as of January I, I945. ${ }^{16}$

In the matter of the freight rate increases sought in 1946 , the Commission made its first report in July and stated that the full amount of the increases proposed by the carriers, as an emergency measure, had not been shown to be reasonable and just. Accordingly, the Commission allowed an increase of only about six per cent in July, but it was able to see the need of this increase being raised to 17.6 per cent - just six months later. The failure or refusal of the Commission to make effective July $x$ the rate increases which it authorized as of January I, I947, undoubtedly had a far-reaching adverse effect upon the financial condition, the credit, and the services of the rail carriers.

Interesting contrasts can be discovered by comparing the financial condition of the railroads with other industries which the public interest has compelled the Government to regulate. From I929 through I945, the electric power and gas, and the telephone and telegraph industries, both regulated monopolies, earned an average of more than five per cent on net worth-on the book value of preferred and common stock plus surplus. During these same years, the railroads earned an average of only a little more than 2.5 per cent on their net worth.

\footnotetext{
${ }^{14}$ Ex parte 148 and I62, Increased Railway Rates, Fares, and Charges, 264 I.C.C. 695 (1946).

${ }^{15}$ Ex parte 148 and 162, Increased Railway Rates, Fares, and Charges, 266 I.C.C. 537 (1946).

${ }^{16}$ Interstate Commerce Commission, Bureat of Transport Economics and Statistics, Monthey Comment on Transportation Statistics 4 (Feb. 13, 1947).
} 
The railroad industry is not a monopoly but its rates and services are subject to review and regulation by the Government. What then is the reason for the unbalanced rate of return which exists as between these three industries? The prime factor is the dilatory and unrealistic process by which railroad rate regulation in relation to return on investment is determined and administered by the Commission. Too lengthy delays may determine at once whether the railroad industry will operate profitably or not. A rate of return on investment for an entire industry of only about 2.5 per cent is bound to be fatal to some of its members.

In amending the Interstate Commerce Act of r920, the Congress certainly never intended that the return on the money invested should fall to a point where the national transportation system should be so weakened that the Government would have to take over and operate the railroads. Yet road after road has been forced into costly bankruptcy or trusteeship in the last fifteen years. It is most likely that with such a possibility in mind the Congress specifically set forth in the Act of I920 that 5.5 to 6 per cent constitutes a fair and reasonable industry-wide return on the value of the property.

The property, material, and supplies of the railroads represented an investment of 20.5 billion dollars in 1920 . The following year the railroads collected 5.5 billion dollars in revenues. After paying operating expenses and taxes, 6or million dollars of net railway operating income remained, or a return of 2.9 per cent on investment. During the twenty-five following years, the 20.5 billion dollar investment was increased to about 28 billion dollars. From this greater industry, the owners had reason to expect more work and larger returns.

In 1946 the industry did perform by far more work than in rg2r. The railroads hauled 90 per cent more freight and carried 80 per cent more passengers. Revenues, however, were only $3^{8}$ per cent greater despite the added investment and the handling of nearly twice as much traffic. Net railway operating income amounted to 6rg million dollars in 1946 compared with 601 million dollars in I921, or a return of 2.2 per cent on investment in 1946 against 2.9 per cent in the earlier year. In addition, over one-fourth of the net railway operating income reported for 1946 consisted of non-recurring tax credits. As a result, the railroad security holders' investment dollar really earned only I. 6 per cent in 1946 in spite of the heavy traffic carried. For the railroads to be restored as vital revenue-producing properties, a much more realistic rate of return is required.

\section{IV}

Competitive factors, always part of the practical aspect of rate-making, will have to be given even greater weight in the future. Consideration of these factors is a natural deterrent to uniformity in the railroad rate structure. Thus, the problem of removing discriminations which may be found will be further complicated by the fact that the Interstate Commerce Commission is no longer the absolute czar of transportation affairs in the United States. The fledgling airline industry of ten 
years ago has, through the speed of war developments and the magnitude of war expenditures, quickly reached maturity and become an important component of our national transportation system. The Commission has absolutely no control over airline affairs nor the impact of airline affairs on the railroads or the other modes of transportation.

About go per cent of our inland transportation needs, both passenger and freight, were serviced by the railroads prior to 1920. Since that date there has been a renewed use of the inland and coastwise waterway system, together with increased utilization of the intercoastal waterway system through the Panama Canal, the passenger automobile, truck, bus, pipe line, and airplane. By 1940, the railroad portion of total commercial ton-miles in the United States, excluding substantial coastwise and intercoastal traffic, was reduced to $\sigma_{2}$ per cent. The railroad share of total passenger miles, excluding phenomenal private automobile traffic, was by coincidence down to about the same percentage. The nature and characteristics of coastwise, intercoastal, and passenger automobile traffic make it statistically unwise to include data on these media in the computation of total commercial traffic used for 1940. Were this possible, reduction in the railroad share of freight traffic would have been greater and of passenger traffic much greater. Just as the transportation problem today is no longer a railroad problem, no longer can it be assumed by the Interstate Commerce Commission and the Congress that railroad affairs "will straighten out somehow," because the virtual traffic monopoly of the railroads is definitely past.

The original Interstate Commerce Act of I887 applied only to the railroads. Later, pipe line common carriers were made subject to regulation by the Interstate Commerce Commission. ${ }^{17}$ From I935 to I942, the jurisdiction of the Commission was gradually extended to cover interstate operations of trucks and busses, domestic water carriers, and freight forwarders. ${ }^{18}$ In 1938, the air carriers, however, were made subject to a new and separate regulatory body which is now known as the Civil Aeronautics Board. ${ }^{19}$

The declaration of National Transportation Policy contained in the Transportation Act of I940, and quoted at the beginning of this article, appears to be deficient in at least one respect, in that it sidesteps the existence of the separately stated policy and separate regulatory body for aviation established by the Civil Aeronautics Act of $193^{8}$. The declaration of policy for air carriers appears in Title I, section 2 of this latter Act:

In the exercise and performance of its powers and duties under this Chapter, the Board shall consider the following, among other things, as being in the public interest, and in accordance with the public convenience and necessity-

(a) The encouragement and development of an air-transportation system properly adapted to the present and future needs of the foreign and domestic commerce of the United States, of the Postal Service, and of the national defense;

${ }^{17}{ }_{24}$ STAT. 379 (I887), as amended, 49 U. S. C. \$I(I) (I940).

1849 StaT. 543 (1935), 49 U. S. C. \$301 et seq. (1940); 54 Stat. 929, 49 U. S. C. \$901 et seq. (1940); 56 Stat. 284 (1942), 49 U. S. C. A. \$roor et seq. (Supp. 1946).

${ }^{19} 52$ STAT. 973 (I938), as amended, 49 U. S. C. $\$ 40$ I et seq. (1940). 
(b) The regulation of air transportation in such manner as to recognize and preserve the inherent advantages of, assure the highest degree of safety in, and foster sound economic conditions in, such transportation, and to improve the relations between, and coordinate transportation by, air carriers;

(c) The promotion of adequate, economical, and efficient service by air carriers at reasonable charges, without unjust discrimination, undue preferences or advantages, or unfair or destructive competitive practices;

(d) Competition to the extent necessary to assure the sound development of an airtransportation system properly adapted to the needs of the foreign and domestic commerce of the United States, of the Postal Service, and of the national defense;

(e) The regulation of air commerce in such manner as to best promote its development and safety; and

(E) The encouragement and development of civil aeronautics. ${ }^{20}$

A study of the policy passages of the Civil Aeronautics Act of $193^{8}$ and the Transportation Act of I940 reveals general similarities. The statement of policy contained in the Civil Aeronautics Act, however, is unique for two reasons. In the first place, it directs the Civil Aeronautics Board (originally designated the Authority in the Act) to foster the development of air transportation, without any mention of consideration being given to the effect of such air development on the other formis of transportation. In the second place, it directs the Board not only to regulate air transportation but to encourage and promote its growth. No such emphasis on promotion is contained in the statutes with regard to the carriers under jurisdiction of the Interstate Commerce Commission, although the Commission is generally directed to foster sound economic conditions among the several carriers "all to the end of developing, coordinating, and preserving a national transportation system by water, highway, and rail as well as other means." The phrase "as well as other means" should be noted. If it were meant to cover air transportation, it is far too vague to have any legal or practical effect.

The upshot of these two inconsistent statements of National Transportation Policy is that we have the Civil Aeronautics Board required to consider the development of aviation alone, and the Interstate Commerce Commission ordered to develop a complete national transportation system when it has no authority over air, which is now not only a principal component of such a system but the fastest developing one.

Infancy is an outmoded plea for the airlines today because they have long since grown beards and gone off to fight our wars admirably. In the summer of 1946, air passenger travel attained a rate of 7.5 billion passenger-miles per year, and air passenger revenues in August of that year amounted to 75 per cent of the railroad passenger revenue in Pullman cars. But when the Civil Aeronautics Act became law in $193^{8}$, air transportation was still on a small scale and the Congress was anxious to promote this new, high-speed medium in every possible way. With that in view, civil air carriers were singled out for Governmental financial aid far exceeding that ever enjoyed by any other American public utility or industry. The

${ }^{20}{ }_{52}$ STAT. 980 (r938), 49 U. S. C. $\$ 402$ (r940). 
key public-aid provision, which appears in Title IV, section 406(b) of the Act, reads, with italics supplied, as follows:

In determining the rate in each case, the Board shall take into consideration, among other factors, the condition that such air carriers may hold and operate under certificates authorizing the carriage of mail only by providing necessary and adequate facilities and service for the transportation of mail; such standards respecting the character and quality of service to be rendered by air carriers as may be prescribed by or pursuant to law; and the need of each such air carrier for compensation for the transportation of mail sufficient to insure the performance of such service, and, together with all other revenue of the air carrier, to enable such air carrier under honest, economical, and efficient management, to maintain and continue the development of air transportation to the extent and of the character and quality required for the commerce of the United States, the Postal Service, and the national defense. ${ }^{21}$

Rigid interpretation of this provision practically insures the solvency of every certificated airline which carries the United States mail. The provisions appear mandatory. The Board is required to set air mail pay at a level which, together with all other income, will maintain the carrier in business and provide revenues adequate to attract new capital as needed. This necessarily means a level which will yield a profit. If the Board errs therefore in fixing an air mail pay rate for the future which is too low, and a carrier consequently encounters financial difficulties, the carrier can go back to the Board for more mail pay. Upon proof of these facts and a showing that management of the carrier has been honest, economical and efficient, the Board seems compelled to grant increases for retroactive application. When the railroads must face this type of spoon-fed competition from "Baby Aviation," the least the Interstate Commerce Commission can do is to act speedily on their requests for increased passenger and freight rates designed to minimize imminent losses. Airlines recently received approval of an industry-wide passenger fare increase from the Civil Aeronautics Board in a few days.

\section{$\mathrm{V}$}

Related to the inadequacy of the railroad revenues and the increased importance of competitive factors, notably those concerning air transportation, are the unbalanced subsidy and taxation policies of the Government in regard to the various modes of transportation. The over-all income of the railroads is thus effectively limited. This policy again creates a normal reaction on the part of railroad managements to oppose reduction of specific rates. The inequities worked through public subsidies and tax differentials form a principal virus threatening the health of our national transportation system today. While the nature and extent of public aid is invariably a complicated and controversial question, this does not mean that reasonable indications of it cannot be ascertained. All forms of transportation, except pipe lines, have received public assistance at some time in their history although there has been considerable variance in the kind and amounts.

$$
{ }^{21} 52 \text { STAT. } 998 \text { (1938), } 49 \text { U. S. C. } \$ 486 \text { (1940). }
$$


Public aids to the railroads entirely benefited a common carrier system. Aids to the highways, waterways, and airways have benefited commercial users, but the facilities developed were also available for non-commercial use. The degrees to which the latter was true necessitate allocations of the total aid. This requires acts of judgment and accordingly lays the foundation for dispute.

Fortunately, one of the subjects on which the temporary Board of Investigation and Research, created by the Transportation Act of 1940, made a report was Public Aids to Domestic Transportation. ${ }^{22}$ This report was issued in September, 1944, just as the Board expired, and contained much valuable information. There was also an earlier, but less meritorious, report, entitled Public Aids to Transportation, issued by the Federal Coordinator in $1940^{23}$ Both of these studies have supplied material for the discussion which follows.

Land grants, chiefly in the West and South, constituted the principal form of public aid to the railroads and were made to facilitate construction of lines in unsettled territories. The Board of Investigation and Research found that total land granted amounted to about I79 million acres, of which 73 per cent was contributed by the Federal Government and 27 per cent by nine individual states. Present Federal land-grant mileage is about 17,500 , or approximately seven per cent of the total miles of railroad lines in the United States. The lands, largely conferred between $185^{\circ}$ and 1870 , varied greatly in quality and potential value.

The value of this aid is a highly debated question. The Federal Coordinator concluded that the total net aid amounted to $x, 443$ million dollars, but this figure was based on intricate calculations much too inclusive and much broader than landgrant aids, the principal medium of railroad subsidy. The Board of Investigation and Research arrived at a figure of 495 million dollars for land-grant aid and the Bureau of Railway Economics at one of 148 million dollars. Disagreement in these two latter estimates centers largely around whether the amount of aid in monetary terms is properly measured by the net value which the railroads realized from the lands or by the value of the lands at the time of grant.

Regardless of the true figure, this aid to the railroads is generally held to have been a sound public investment because the beneficiary railroads agreed to rate reductions on mail, Government property, and Federal and military personnel. Competing railroads, which did not receive land grants, voluntarily equalized their rates with the land-grant roads in order to receive their share of the Government traffic. Coverage of the exemption was reduced to military freight and personnel in $1940^{24}$ The exemption was finally entirely abolished in October, $19466^{25}$ As of the end of 1945, calculations by the Bureau of Railway Economics indicated the savings to the Government were already well over one billion dollars.

22 Bonrd of Investigation and Research, Public Aids to Domestic Transportation, H. R. Doc. No. 452,79 th Cong., Ist Sess. (1945). (1940).

${ }^{3}$ U. S. Office of Federal. Coordinator of Transportation, Public Aids to Transportatica

2454 STAT. 954 (1940), 49 U. S. C. A. $\$ 65$ (Supp. 1946).

${ }^{25} 59$ STAT. 606 (1946), 49 U. S. C. A. $\$ 65$ (Supp. I946). 
An examination of the subsidy record for the railroads reveals therefore that historically they did not all finance their own way, but where this is true the debt has been repaid for the greater part. In addition, the railroads own and maintain their own rights of way and structures, which account for about 70 per cent of their investment, and pay ad valorem taxes on this property. Only the pipe lines pay similar taxes. Moreover, these taxes paid by the railroads are devoted to general governmental purposes-even to the extent of participating in subsidy contributions to their competitors.

Turning to public aids to highway transportation, the Board of Investigation and Research found an aggregate expenditure of $4 \mathrm{I}$ billion dollars by Federal and state agencies for highways, roads, and streets for the period I92I through I940. Of this total, about $I_{5}$ billion dollars was spent on primary highways. Secondary roads accounted for another $\mathrm{r}_{3}$ billion dollars; town and city streets for a like amount. About I93I, Federal participation in the highway program increased sharply until it amounted to $3^{6}$ per cent of total expenditures in $193^{8}$.

The extent to which highways have become financially self-sustaining has had varied interpretations. The Federal Coordinator's report of 1940 concluded that "motor vehicle users as a class have paid their way since 1927." The Board of Investigation and Research stated in 1944 that "a comparison of costs and road-use payments shows that in recent years the general class of motor vehicle users has contributed amounts fully adequate to meet an equitable share of the total annual economic costs of roads and streets." While the two reports are in accord that motor vehicles now generally pay a little more than their fair share of highway costs, the studies are not in agreement in one important respect.

The Federal Coordinator stated that the users of private automobiles ( 87 per cent of all motor vehicles in I940) fell slightly short of paying their full share of highway costs and that the deficiency was met by overpayments from trucks and busses. The Board of Investigation and Research report, on the other hand, found four years later that the private automobiles pay more than their fair share and that most of the larger vehicles pay less.

A tabulation in the Board of Investigation and Research report of annual costs of all highways, roads, and streets chargeable to privately owned motor vehicles, compared with state and local highway user revenues, by types of vehicles, for the year I940, was very revealing. It showed the average charge for all vehicles (automobiles, busses, and trucks) was $\$ 37.62$ per vehicle for highway costs. Contributions in gasoline taxes and registration amounted to $\$ 39.82$, or an excess payment of $\$ 2.20$. The breakdown of the vehicles by individual classes, however, indicated that about the only class of vehicle which made an overpayment was the private passenger automobile, charged with $\$ 28 . \mathrm{I}_{3}$ and contributing $\$ 33.3 \mathrm{I}$, or an excess of $\$ 5.18$. The intercity busses, for example, were charged with $\$ 1,045.24$ and paid only $\$ 765.57$. Non-farm trucks with capacity of five tons or more were charged with $\$ 362.28$ and paid only $\$ 260.62$. Combination trucks (tractors with trailers) were charged with 
$\$ 702.08$ and paid only $\$ 429.15$. Professor William J. Cunningham, writing in the Harvard Business Review last fall, concluded on analysis of these data in the tabulation of the Board of Investigation and Research that "the figures indicate that the busses and trucks competitive with railroads were subsidized, and that the subsidy was paid by the private automobiles." 26

On the taxation side, the payments made by highway users in gasoline taxes, registration fees, drivers' licenses, and the like may not be clearly regarded as taxation. They are really charges for the use of publicly owned highways. Collections from these sources do not go into funds for the general expenses of government but are earmarked for highway construction, maintenance, policing, and other such expenses which bring a direct benefit only to the motor carriers. Furthermore, these user charges, as paid by the commercial motor carriers operating the heavier vehicles, do not compensate the Government fully for maintenance, amortization, and interest on the highway investment.

Even waterway proponents admit that domestic water carriers are subsidized. The Board of Investigation and Research found that the Federal Government made appropriations for improvements in rivers and harbors of 2,723 million dollars through the fiscal year 1940. An additional 443 million dollars was appropriated for lighthouses, beacons, and buoys. Over 80 per cent of these monies was made available after 1890 . The figures do not include data on the New York State Barge Canal System or other substantial state and municipal aids.

All of this terrific outlay of public monies was, of course, not entirely for navigation, and the problem of joint costs is presented in matters of water transportation just as it is in the case of highway use. Apportionment, however, is a matter of small import in discussions of aids to domestic water carriers because the users pay nothing whatever to reimburse the Government for the navigation cost of the waterway projects. Traffic through the Panama Canal marks the single exception. Comparisons of cost of transportation by water, as against cost by the other modes of transportation, are therefore highly unfair because the hidden costs, which are borne by the taxpayers, are not revealed. Also, by any standard of equal taxation, water transport does not carry an equitable share of the tax burden. The tax bill on its vessel property is negligible.

Public aids to air carriers are on a scale of great magnitude and are of highly current interest. Subsidy to the airlines through public construction of the airports is only one medium through which they receive Government aid. They contribute only token sums for maintenance and use of the airports, have almost free use of the airways constructed, maintained, and operated by the Federal Government, are paid for carrying the mail on a "need" basis to insure sound finances, and do not bear their fair share of the tax burden.

So universal has become the practice of public construction of airports and air terminals that the airlines have come to assume that this constitutes a vested right, and

${ }^{20}$ Cunningham, The Transportation Problem, 25 Harv. Bus. Rev. 58, 72 (1946). 
complacently expect the public to bear this burden, the most expensive part of the commercial aviation investment. In I946, the Harvard Business School made an independent study of terminal airport financing and management. It states at the very beginning:

The increasing size of airport costs makes the problem of airport management a major concern both for the owners of public airports and for those who use them. Within a comparatively few years the total investment in terminal-type airports may pass the \$2 billion level. By then, the annual costs of operating such airports, currently estimated at $\$ 58$ million (including interest and depreciation), will have become almost \$200 million.

The relative size of the prospective $\$ 200$ million annual airport operating expense is emphasized by the fact that the reported assets of all domestic airlines as of mid-r945 were only $\$ 213$ million, and total profits for 1945 were just under $\$ 34$ million. Although these airlines are not the sole users of terminal-type airports, they do account directly or indirectly for the bulk of the present relatively small airport revenues. ${ }^{27}$

Through I944, over one billion dollars of public funds was expended for civil airports in the United States, according to figures of the Civil Aeronautics Administration. Over three-quarters of the expenditure was for the larger terminal-type airports, the size and cost of which are for the most part determined by the needs of the commercial airlines, as distinct from the lesser requirements of private flyers.

In 1945, about 73 million dollars was spent on civil airports. The new Federal Airport Program for 1946-r953 calls for the expenditure of another billion dollars to be composed of two Federal and state-municipal shares of 500 million dollars each.

In addition, to cite a single instance, the city of New York has just turned over its airport development to the tax-exempt Port of New York Authority, which plans to raise at least another Ioo million dollars over and above public contributions already made or contemplated for the city program. If this plan is consummated, railroads in the city of New York face about 300 million dollars of tax-free terminal competition constructed with public or quasi-public funds.

Maintenance of the airports used by airlines, including snow removal, lighting and repair of runways, and police and fire protection, is invariably paid for by the taxpayers of the local government sponsoring the airport. Airline operations usually take priority over private flying at the large terminal airports, so as to make impracticable any cost allocation based on proportional fight activities. Few cities keep accurate financial records of expenditures and costs at their airports. The taxpayers accordingly cannot ascertain the local operational subsidy given the airlines, but it is large.

The airlines make commercial use of the costly Federal airways practically free of charge except for their nominal user contributions through gasoline taxes. These airways are equipped with visual beacons and directional radio beams provided, maintained, and operated by the Federal Government. Continuous and specialized weather information is also provided gratuitously. Take-offs and landings of the commercial airliners are directed by Federal employees in the airport control towers.

${ }^{27}$ Bollinger, Passen, and McElfresh, Terminal Airport Financing and Management 3 (i946). 
The question of air-mail subsidy is also a complicated one. In recent years, the air-mail activities of the Post Office Department have paid their own way, but the proportionate profits which the Department has obtained from air mail, as against railroad mail, are very much out of line. If the new five-cent air-mail rate had applied to the actual air-mail poundage carried in fiscal year 1945, the Post Office Department would have realized a profit of only 2.7 cents per pound as against 37.9 cents per pound at the three-cent rate by surface transport. This would have meant a reduction in profit of 35.2 cents or 93 per cent for every pound of first-class mail transferred from surface to air transport.

The Post Office Department is dependent on the profits of first-class mail to meet the deficits of other classes of mail and special services. To the extent that profit on first-class mail is reduced, the finances of the Post Office Department suffer proportionately. In fiscal year I946, the Post Office Department paid the airlines about 27 million dollars for transporting approximately 24 million pounds of air mail. The railroads were paid 22 million dollars for transporting and providing distributing facilities for around 387 million pounds of non-local first-class mail. To put it another way, the railroads handled 94 per cent of the total non-local first-class mail by weight but received five million dollars less than the airlines received for carrying six per cent of the total weight. The diversion of substantial volumes of mail from the railroads to the airlines, while profitable to the airlines, is certainly detrimental to the the revenue of the Post Office Department and the railroads.

What the public pays for stamps determines the profit or loss of the Post Office Department. The amounts paid to the railroads and the airlines for carrying the mail are determined by the Interstate Commerce Commission and the Civil Aeronautics Board. The railroads now receive about 3.07 cents per ton-mile for carrying first-class mail. The four major airlines obtain about 45 cents per ton-mile. Recent studies indicate that this rate of payment exceeds costs to the airlines by at least 50 per cent. The amount of subsidy received via mail payments by the twelve lesser airlines is much greater. They receive about 92 cents per ton-mile. AllAmerican Aviation, the experimental mail pick-up service, is paid \$12.87 per ton-mile. The average mail payment for all the seventeen major domestic airlines amounts to 52.13 cents per ton-mile.

The airlines contribute little or nothing to the general upkeep of government by way of taxes. Their principal contribution lies in gasoline taxes, and these amounted to only I.5 million dollars in I940-a very nominal airway user charge. The total cost of operating the Federal airways was over 16 million dollars in the corresponding fiscal year, but only one-half of this I.5 million tax contribution went to the Federal Government. The enormous airport developments, unlike railroad terminals, are invariably municipally or government owned and cause tax loss rather than the creation of new revenues. Concurrently, the noise and congestion of airport traffic tends to depress property values and property development in the locality, usually 
one which would normally be comprised of expensive suburban dwellings. This results in still further decreases in tax returns.

The enormous subsidies to motor, water, and air transportation give these media a tremendous competitive advantage over the unsubsidized railroads. The solution to this competitive inequality is not to be found in equalizing the subsidy to motor, water, and air carriers with subsidies to railroads. The remedy lies in ending all subsidies. No mode of transportation, which is competitive with the railroads today, is still in a development period during which subsidies are justified. It is highly important to a healthy transportation system in this country that all the agencies be made self-supporting. Otherwise, free enterprise will perish in the transportation field.

\section{VI}

One reason the Federation for Railway Progress was formed in February, 1947, was to implement the National Transportation Policy contained in the Act of 1940. At that time, it was stated that the new Federation sought:

(I) To inform the public about all matters pertaining to American railroads, and particularly to keep before them the facts regarding any deterrents to the full accomplishment of the purposes of the Federation;

(2) To modernize railroad equipment and facilities and otherwise improve rail- , road passenger and freight services so that the public will have available a more efficient transportation system in the interest of the national safety and the public convenience;

(3) To bring about an equitable balance among wages, return on investment, and rates in the railroad industry so that employees, investors, and the shipping and traveling public will all receive fair treatment;

(4) To staff railroad management with progressive, energetic, efficient personnel who have full confidence in the future of railroads in the United States;

(5) To abolish monopolistic practices and bring about the return of free enterprise to the railroad industry.

In activating this first goal, the new Federation for Railway Progress plans to prevent freight-rate muddles and railroad muddles of every sort in the future. Already through its monthly publication, Railway Progress, the Federation has begun to concern itself with all aspects of the railroad industry and to regard them clinically.

Considerable sentiment exists for revision of the regulatory acts and for the reorganization of the regulatory bodies. Some feel that the dissatisfaction which exists with the administrative malpractice of the Interstate Commerce Commission on the one hand, and the pampering by the Civil Aeronautics Board on the other, can best be eliminated by placing all the forms of transportation under one new regulatory body.

Certainly as a minimum program the activities of the Government in the business 
of transportation should be subjected to the same standards which apply to transportation agencies privately owned and operated. Government programs which aid transportation should be carefully evaluated in the light of public need, financial soundness, and possible detrimental effect upon existing carriers. Taxation should not continue to put any one form of transportation at a disadvantage such as it now imposes on the railroads. The public interest definitely requires the imposition of reasonable user charges on trucks, busses, vessels, and airplanes so that competition may be equalized and the Government may be fairly compensated for its expenditures in providing the facilities which are used by these types of carriers for private profit. Generally, the inherent advantages of each of the modes of transportation must not be thrown out of balance by the creation of new and dangerous artificial disadvantages. Our system will not wax strong if we continue to deny a healthful ration to the principal agency of transportation and spoon-feed all the others.

The aim of our National Transportation Policy should be to nurture a system adequate to service all the transportation requirements of the United States in war and in peace. Until defects in the policy, such as those we have discussed, are corrected and the policy itself is revitalized by proper administration, there appears no adequate basis for effectively settling disputes about discrimination in the regulation of rates or in the conduct of other carrier functions. 
. 